\title{
China English as a Variety of English and its Implications on ELT in Chinese Context*
}

\author{
Furong Kou \\ Research Institute of Foreign Language Education \\ School of English Education \\ Xi'an International Studies University \\ Xi'an, China
}

\begin{abstract}
This paper aims at exploring China English, in comparison with Chinglish, also the inetrlanguage of English, as one of varieties of world Englishes, with its unique features, resulting in discussing the appropriate attitudes Chinese learners of English should have and corresponding implications on ELT in Chinese context.
\end{abstract}

Keywords-China English; world Englishes; features; attitudes; ELT

\section{INTRODUCTION}

This paper describes first world Englishes which have significant role in all fields in nowadays world, of which China English, is one of varieties with its unique features and special functions in comparison with Chinglish, the interlanguage for foreign language learners in China. Consequently, the appropriate attitude towards it becomes very important. Then this paper talks the inevitability of teaching Chinese students China English in Chinese context and how to operate both from students and teacher' perspectives practically.

\section{WORLD ENGLISHES}

It was early in ancient time that trade and cultural communication between China and other countries already began. With the increasing fusion of culture communication and economic interaction, there was consequently a necessity of using some common vocabularies which could be understood by both Chinese and foreigners in communication at that time. Then some common vocabularies frequently used to describe Chinese-specific things like "shantung (a kind of silk in Shandong province), pekin (a kind of wide silky cloth in Beijing), silky, silkiness, china" emerged gradually [23]. English versions of Chinese classic works like Four Books and The Five Classics also appeared to transmit Chinese culture into other cultures. [17].

With the rocketing speed of globalization, the impact of those vocabularies on not merely economy and politics, but also linguistics, reflects social development. Consequently,

*This paper is supported by Xi'an International Studies University (research project: The research into effectiveness of foreign language teaching by using knowledge visualization representation tools, No.16XWB03)
Chinese development produced neologisms like "Deng Xiaoping Theory, Four Cardinal Principle, the principle of 'one country, two systems' etc." Therefore, the great importance to take a closer look at these neologisms stands out.

Some scholars pointed out that these above neologisms actually belong to "China English" [16] [19]. China English, which is believed to be one of the varieties of English in China especially for cultural communication, is related to theory of "World Englishes".

The famous Indian linguist Braj B. Kachru believes that the concept of "World Englishes" was first proposed in the late 60s [19] [5]. In 1980, John Benjamin published the first magazine English World-Wide with all kinds of Englishes as the target. In 1985, Cambridge University Press and Pergamon both published English Today and World Englishes, the two famous international academic journals relating to the study of English language used today[19] Many scholars focus on English varieties such as Australia English, Sinapore english, South African English, Indian English, Malaysia English and China English, and so on. In Kachru's theory of "World Englishes", the Theory of Three Concentric Circles describing English in different countries is the most famous. This theory has divided Englishspeaking countries into three circles: inner circle, outer circle and expanding circle [8] [6]. Among the three circles, the inner circle includes countries of USA, UK, Canada, Australia, and New Zealand; the outer circle includes Bangladesh, Ghana, India, Kenya, Malaysia, Nigeria Pakistan, Philippines, Singapore, Sri Lanka, Tanzania and Zambia; the expanding circle includes China, Caribean countries, Egypt, Indonesia, Nepal, Saudi Arabia, South Africa, South America, Taiwan, CIS and Zimbabwe. From his theory, it seems that English has not the differentiating features as a second language in many countries. The English language spoken in China can be ascribed to one of World Englishes. Apparently, varieties of English appear in outer circle and expanding circles. All of these varieties actually challenge the position of Standard English. Even in the inner circle, there are some varieties, apart from some dialects.

Early in 1980, Ge Chuangui first proposed the concept of "China English" and differentiated between Chinese English 
and China English [16] in one of his articles about ChineseEnglish translation. His effort aroused scholars' great interest later on.

However, the assertion that China English is a variety of English is oppugned. Some scholars argue that the absence of colonization in China's history results in the vacancy of Chinese variety of English. Even further, some scholars insist that there is still no variety of English in China, but only Chinese English, the interlanguage for Chinese learners of English, due to the nonexistence of prominent linguistic features. Qiu Lizhong and Ning Quanxin once wrote an article to question Jiang Yajun's comment, and contend that it is too early to propose China English, since the three levels (phonetics, lexicon and discourse) of so called "China English" are all hard to hold firmly [22]. To make things worse, it is possible to make hybrid English prevalent and result in fossilization of interlanguage.

The first opposing view has attributed varieties of Englishes greatly to colonization course, which emphasized history of English in some specific country too much. However, not all the varieties of English have undergone colonization but the criterion is whether "it is because of the history of the language community" [14]. That is, in their views, "language community", not "colonization" is the decisive factor. The second opposing view focuses on the attitude and standpoint of looking at the criteria of variety of English, which will be elaborated in the third part.

\section{China ENGLISH}

In this part, three perspectives will be included, one is China English and Chinese English, the other two are China English as one of the Variety of World Englishes, and features of China English. This part starts with the distinction between China English and Chinglish, since the two are very easily to be mistaken. After knowing its difference with Chinglish, then it needs to discuss the identity of China English as one of the varieties of English, and the features of China English in order to have a much clearer understanding.

\section{A. China English and Chinese English}

Although the concept of "China English" has been mentioned many years ago, some scholars still do not accept it as a Chinese variety of English. Aiming at making clear the nature of China English, this paper intends to justify its role as a variety of English though it can be considered as a "developing" variety with its great potential to develop further in China. And the implications on teaching are also mentioned due to its importance since majority of second language learners of English are in China.

To answer Qiu Lizhong and Ning Quanxin's question, it is a must to distinguish China English and Chinese English first. To be specific, Chinese English is also called Chinglish, which refers to an interlanguage, while China English refers to the variety of English, which is usually accepted by most people though there may be some unique features. Hu Xiaoqiong has distinguished Chinese English and China English, who contends that Chinese English and China English stand on the two sides of the continuum without clear boundaries since "it is not possible to place them neatly into two categories[3]. Instead, they are situated on a continuum and progressively merge, which makes some implications for English teaching in China, and explains why we should use China English as the standard alongside American English, British English or other 'world Englishes'. It goes so far that the suggestion we should use China English as a standard is proposed.

Yan Hong (2008, p. 57) believes that Chinglish is "a deformed language" while China English is "normative English" though both with some Chinese characteristics have emphasis on the importance of the academic study of English in China "to both linguistic theories and social reality." [12]

In summary, there is no definition yet about the two terms, but the differences still can be perceived. Generally, in summary, Chinglish is regarded as an interlanguage, while China English is accepted not only by we native speakers of Chinese, but mainly by native speakers of English, even some media and dictionaries adopt some China English, such as "tofu", which can be seen in many printed materials even in inner circle countries.

\section{B. China English as One of the Variety of World Englishes}

Nowadays, terms "China English" and "Chinese English" are frequently seen in many articles of academic journals like World Englishes, English Today, and so on. Scholars have great interest in exploring them. In this paper, the author adopts "China English" to refer to the possible variety of English language in China, though some still use "Chinese English" to refer to China English interchangeably. However, Chinglish is usually mentioned as Chinese English by many scholars. Therefore, in order to distinguish the two terms, the author prefers "China English" to refer to the possible variety of English language in China, and Chinese English consequentlyare used to refer to the interlanguage of English for Chinese learners.

China English also can be perceived from another perspective. Rob Penhallurick (2010, p.200) mentions that Language goes "with attitude" like "dialect, accent, and identity" [10]. It means that regarding China English as a variety of English language is related to the identity of speaker of English as a second language in China. Thus some scholars have analyzed China English from the perspective of cultural identity (He \& Liu, 2008) [18].

China English is regarded as a variety of English. Chen Menlin and $\mathrm{Hu}$ Xiaoqiong "review the acceptability of such an English, both at home and abroad" and believe that it "has the potential (it is argued) to be accepted as a standard variety" [1]. The analysis has conducted the acceptability of neologism (actually, the vocabulary of China English) mainly from five internal factors: demography, geography, codification, authority and acceptability. Among them, the demographic factor "is concerned with number of speakers." And "a large amount of China English vocabulary is accepted as acrolectal, as with kowtow, tofu, and kung fu, but these do not (yet) guarantee a green light for China English as one of the world's Standard Englishes." The geographical factor "relates in particular to the spread of 
neologisms" and "Codification is "putting the innovation into a written form in a grammar, a lexical or pronouncing dictionary, course books or any other type of reference manual'" The acceptability factor is the last stage for a neologism, when it is "once accepted, it will be codified and used naturally." They also conducted a survey to see the people's attitudes (whether and to what extent people accept China English as a variety of English) towards China English abroad. The conclusion is "China English should and will certainly stand alongside other World Englishes" though it still needs time for China English to grow mature.

In terms of its potential, You (2008) recommends context model to analyze China English which indirectly shows the growing potential of China English in rhetorical strategies in electronic media [13].

In terms of its development, $\mathrm{Xu}$ Zhichang contends that China English (but in the article, Chinese English is used to stand for China English since different scholars may use differently) is a "developing member of world Englishes." and draws on Bulter's criteria to measure a variety of World Englishes like:

- A standard and recognizable pattern of pronunciation;

- Particular words and phrases which spring up usually to express key features of the physical and social environment and which are regarded as peculiar to the variety;

- A history - a sense that this variety of English is the way it is because of the history of the language community;

- A literature written without apology in the variety of English;

- Reference works - dictionaries and style guideswhich show that people in that language community look to themselves, not some outside authority, to decide what is right and wrong in terms of how they speak and write their English [14].

What's more, Kirkpatrick and Xu point out that "criteria 4 and 5 provide strong evidence for an established variety. In the context of China, however, it is clear that we are considering a "developing" variety_China English [14].

China English, though young, has aroused scholars' great interest and been regarded as a developing variety by many scholars and researchers.

In summary, Chinese English, namely, Chinglish, emerges as a deformed English, caused by the negative transfer of mother tongue, i.e. Chinese and low English proficiency, mechanically applying English rules and conventions into English language, which is not close to authentic English, eccentric enough, and thus it should be avoided for English learners in China. However, China English arises as the product of localization of English language, based on the relevant English rules. In globalization, it plays an important part in transmitting Chinese culture to the world, which should be promoted for Chinese learners of English in many different fields.
Therefore, we should hold different attitudes towards the two linguistic phenomena for they are quite unique, with different identity and features, in which, the former should be avoided and eradicated, while the latter should be promoted.

\section{Features of China English}

English, as an international language, lingua franca, has its unique significance in the world, with its popularity in many centuries till now. However, with the increasing strengthening of globalization, more and more languages manifest their significance no matter in linguistic, economic or political fields, among which, Chinese is one deserving our special focus. China English, based on English expression and Chinese soul, under the influence of Chinese language, emerges consequently.

China English, both in linguistics and social reality, plays an essential role. Undeniably, unlike Chinglish, there are some features of China English in general. First, it is the product of language communication between Chinese and English. Second, it is not expressions conventionally used by native speakers of English, expressing things in many fields in Chinese context, with Chinese characteristics. Third, it enters into English communication based on Standard English, without the influence of English. Then, it is beneficial for Chinese culture diffusion, and will be enriched as its popularity in Chinese people and the formation of Chinese characteristics, resulting in the development of English language and world culture.

In other words, China English is the way Chinese learners of English used to express Chinese ideologies and special products in English, which will consequently have effect on English teaching in Chinese context.

Then, there are also some specific features, i.e. the linguistic criteria of China English, as one of the varieties of World Englishes. To answer this question, the features at three levels,i. e. at phonetic level, lexical level and discourse level need to be elaborated.

Yan Hong has summarized the lexical features of China English [12]. The author believes that "The lexical features of China English are mainly shown in the Chinese borrowings entering in English" and classifies Chinese borrowings according to the contents such as "xiucai, yamen, dazibao, putonghua fenghuang, etc. (history and culture); pipa, erhu, gongfu, wushu, taichi, yangko, mahjong, qigong, sampan, etc.( recreation and sports); changsam, jiaozi, baozi, chowmein, wonton, tea, congou, maotai, etc.(food, clothing, shelter and transportation (basic necessities of life); fengshui, kang, kowtow, Cantonese, Chingming, typhoon, Beijinger, etc.( About local conditions and customs); Inner Mongolia, Lhasa, Hongkong, Macao, Kowloon, etc. (About geographical names) and yuan, jiao, fen, mu, Li, liang, jin, etc.(measurement units )".

According to the above examples, it can be safe to conclude that, at least, China English has obvious feature at lexical level, then how about its features at other levels? 
The lexical connotation, syntax and discourse features of China English are all elaborated in Xu's book Chinese English: Features and Implications [14]. Lexically, words like "communist" and "propaganda" are mentioned as positive words in China. In syntax, "the sentences in the magazine are 'longer than usual' and that 'nouns with short modification in Chinese often have to be translated into English with embedded sentences." At the level of discourse and pragmatics, it can be expected to be "transferred from Chinese into China English", "the transfer of such norms is an essential criterion if the new variety of English is to achieve acceptance as a marker of identity among its speakers".

Jiang Yajun also argues that China English does not merely have lexical features but also discourse features such as Chinese students writing letters with distinctive discourse and information structure with Chinese characteristics, which proves that China English does have its unique discourse features[20]. Most Chinese learners of English tend to express their ideas according to Chinese way of thinking and expressions. For example, students most apply Chinese "particular-general" model instead of English "generalparticular" model apparently under the influence of Chinese way of thinking. In other words, more Chinese learners of English are apt to Chinese way of thinking, and thus adopting order of Chinese language as information flows. They are not aware of the two quite different ways of thinking and ignore the different narrative sequence.

John Pinkham published The translator's guide to Chinglish in the year of 2000, which is regarded as "the milestone" for beginning translators and English learners[11], which listed many authentic examples of Chinglish, enabling more learners be aware of the mistakes and then thinking about the solutions.In this book, four quite different thing patterns are discussed including oriental people's spiral way of thinking and western people's linear way of thinking. The two thinking patters, in a way, explain indirectly the difficulties and obstacles Chinese learners of English have to tackle in the course of learning English in Chinese context.

According to Pinkham's theory of oriental and western people's way of thinking, it is easier to identify the differences in students' writing features between theirs and native speakers' writing styles.

For native speakers of English, they are more likely to point out the main idea first, then supplying some supporting details while Chinese learners of English tend to explain reasons or state details first and then mention the purpose of doing so, or sometimes without mentioning the purpose at all, leaving readers to draw the meaning by themselves.

Generally speaking, though China English has its features at different levels, the most prominent feature falls at lexical level since it reveals social-cultural element [2] [15] [21].

Therefore, linguistically, it be drawn the conclusion that China English undoubtedly exists in Chinese context as well as in international context. But China English can, and should be analyzed not only from the perspective of linguistics, but also from other perspectives such as the attitude people hold towards it.

\section{ATTITUDES TOWARDS CHINA ENGLISH}

Since China English is one of the essential kind of varieties of Englishes in the world, the attitudes towards it becomes also very significant.

McArthur says that "the use of English as an Asian lingua franca is its now unremarkable use as the world's lingua franca. Both the global and the regional roles are likely to continue expanding to show how important English language is in Asia [7]". It is just because of the importance of English language, there emerge various kinds of varieties of English to meet the needs of social development and communication.

By and large, language is not always a linguistic problem. It, more importantly and inevitably, involves culture and people's belief. What I intend to say, in this part, is that just as Gunnel Melchers and Philip Shaw contend in the book of World Englishes "varieties are often classified by the sociolinguistic criterion of relation to Standard English." [9] .Obviously, American and British English are no more the only two criteria of Standard English, or, it seems that there is no standard English any longer. The s called "standard", namely, criterion differs in various countries.

Rob Penhallurick asserts that "The perception that Standard English is superior to non-standard English arises because Standard English is ... a social fact but not a linguistic fact" [10]. The author contends that there are more than one Standard English, and "in present-day ... there is not only a great diversity of non-standard English but also there are many regional varieties of Standard English [10]", and "Standard English is out of date". Hu Xiaoqiong even goes so far to suggest China English stand alongside British, American, and other world Englishes, which will overthrow the dominant role of "Standard English".

Many scholars tend to attach importance to China English, linguistically and culturally. The attitude we should hold, is to be aware of it and explore its features and development to cater for the academic study as well as social development in terms of linguistics and other perspectives.

\section{IMPLICATIONS ON ENGLISH LANGUAGE TEACHING IN CHINA}

Jin Lixian and Corarzzi mention that English language teaching (ELT) in China has retained some of its essentially "Chinese characteristics" [4].

One of the features is employing native speakers of English. However, the question is "Are these native speakers employed by the schools in China to teach students English courses qualified for their teaching position? ". During my about fifteen years' teaching experience, esp. after talking with some foreign (native) teachers, I found that some of them have never received special training for English education, let alone being graduated from some education majors. Among the approximately twenty foreign teachers 
(esp. native speakers of English), only one of them, I remember, majors in Education. Some of them even do not have Bachelor's degree. Therefore, when sometimes students ask them some grammatical questions, some of them just say they don't know or avoid answering them. However, I also admit that, with the time going on, more and more foreigner teachers come to China to teach college students English, with their academic background.

Therefore, for English education in China, there are some blind views, in which employing foreign teachers, or native speakers, not only for oral course nut also for other courses, without considering their educational background, is one of features.

This is one specific problem that I intend to point out in ELT in China nowadays; however, it does not mean that all the foreign or native speakers are not qualified enough. What I want to emphasize is that whenever we employ a teacher, his/her education background, or expertise is a key factor to take into consideration. Of course, some universities pay more and more attention to their foreign teachers' expertise for the good of education quality.

Another problem in English language teaching in Chinese context is that the teaching contents, like China English, should be paid attention. Undeniably, an increasing number of teachers have become realized the importance of China English no matter for political and economic purpose or for academic purpose.

Consequently, for application of China English in academic context in China, especially for education purpose, it can be analyzed form two perspectives: from teachers and from students themselves.

From the perspective of teaching, there are some requirements for both foreign teachers and domestic English teachers. For the implications for teaching, the first task is to teach students how to avoid producing Chinese English but gradually accept China English, and let them realize it as a continuum from Chinese English to China English. Hu Xiaoqiong (2004) has proposed suggestions for teaching, such as to "integrate China English into textbooks and other teaching material; let students be widely exposed to world Englishes and take communicative responsibility for what they themselves say" [3]. In other words, adequate exposure is necessary for learning China English based on students' higher language proficiency both in Chinese and English.

Teaching China English in China also requests domestic teachers to achieve great qualifications as well as teachers of native speaker of English. Being well equipped with knowledge in Chinese context and having awareness of importance of teaching China English is a must. Even foreign teachers are employed, they should be aware of teaching students knowing the significance of China English and how to express things with Chinese characteristics in English from the perspective of native speakers of English.

In terms of teaching methods, what's more, code-mixing or code-switching can be allowed in the class [4], since exchange of mother tongue and foreign language can benefit teaching and learning effectiveness as well. In authentic
English teaching practice, mother tongue should be allowed when necessary to enhance students' understanding and better their memory, but of course not always used.

From the perspective of students, first, they are expected to be aware of the importance and try to learn actively to accept those pieces of new information related to China English, i.e. those knowledge closely related to China' development and policies etc.. Second, they need to know that there are some differences between Chinglish and China English, and people cannot randomly translate some items and label them as China English. Third, they have to shoulder the responsibility to transmit cultures to the world by using some China English in the future based on their language ability.

No matter for teachers and students, both of them have to fully realize the differences between Chinese and English languages first, reach an agreement about the real existence of China English, and be aware of the its importance in world communication now and in the future.

\section{CONCLUSION}

In summary, since teachers and scholars should perceive China English with a view of development, the teaching methodology should be adjusted to it accordingly with considerable awareness in order to lay foundation for students to explore the mystery of China English in the future.

In summary, the implication on English language teaching in Chinese context are illustrated mainly from two perspectives, one is from the perspective of teachers, no matter for foreign teachers or domestic teachers, the other is from the perspective of students.

\section{ACKNOWLEDGMENT}

R.G.B. thanks for grant of XISU research project, the research into teaching effectiveness in light of application of knowledge visualization tools.

\section{REFERENCES}

[1] Chen, M. \& Hu, X.. "Towards the acceptability of China English at home and abroad" English Today, 2006, 22(4), pp.44-52.

[2] Gao L. "The lexical acculturation of English in the Chinese context". Studies in Linguistic Sciences, 2001,31(2), pp.73-88.

[3] $\mathrm{Hu}, \mathrm{X}$. "Why China English should stand alongside British, American", and the other world Englishes. English Today, 2004,20(2), pp.26-33.

[4] Jin, L. \& Corarzzi, M. "English language teaching in China: A bridge to the future". Asian-Pacific journal of Education,2002, 22 (2), pp.5364.

[5] Kachru, B. "Standards, codification and sociolinguistic realm: The English language in the outer circle". In R. Quirk \& H.G. Widdowson (Eds.), English in the world (pp.11-30). Cambridge: Cambridge University Press, 1985.

[6] Kachru, B."World Englishes: approaches, issues and resources". Language Teaching, 1993,25 (1), 1-14.

[7] McArthur, T. "English as an Asian language". English Today. 2003,19(2), pp.19-22. 
[8] Mckay, L.\& Bokhorst-Heng, W. Interantional English in its sociolinguistic context. New York: Routledge, 2008.

[9] Melchers, G. \&Shaw, P. World Englishes. New York: Oxford University Press, 2003.

[10] Penhallurick, R. Studying the English language. UK: Palgrave Macmillan, 2010.

[11] Pinkham, J. The translator' guide to Chinglish. 2000, Beijing: Foreign Language Teaching and Research Press.

[12] Yan, H. "On lexical characteristics of China English”. Sino-US English Teaching, ,2008, 5(5), pp.55-58.

[13] You, X. "Rhetorical strategies, electronic media, and China English". World Englishes,2008, 27 (2), pp.233-249.

[14] Xu, Z. Chinese English: Features and Implications. Hong Kong, CHN: Open University of Hong Kong Press, 2010, p. 24. Retrieved Sep.20, 2011, from http://site.ebrary.com/lib/nielib/Doc?id=10426619\&ppg=31 .

[15] Du, R. \& Jiang, Y. "The literature review of China English in the recent two decades". Foreign Language Teaching and Research,2001, 33(1), pp.37-41.

杜瑞清, 姜亚军. 近二十年 “中国英语” 研究述评. 外语教学与 研究, 2001, 33(1),37-41.

[16] Ge, C. On some problems in Chinese English translaiton.Transaliton Communications, 1980, (2), pp.13-14.

葛传槼. 漫谈由汉译英问题。翻译通讯 1980，（2），13-14.

[17] Ma, Z. \& Ren, R. The translation history of Chinese classics. Wuhan: Hubei Education Press,2003.

马祖毅, 任㭉珍. 汉籍外译史. 武汉: 湖北教育出版社, 2003.

[18] He, C. \& Liu, J. On cultural identity of China English. Journal of Southwest University of Science and Technology,2008, 25 (4), pp.8690.

贺春艳，刘景霞. 中国英语的文化身份. 西南科技大学学报， 2008, (254), 86-90.

[19] Jiang, Y. The literature review of World Englishes in the last two decades. Foreign Language Teaching and Research.1995, 33(1), pp.37-79.

姜亚军. 近二十年 World Englishes 研究述评. 外语教学与研 究, 1995, 33(1), 13-19.

[20] Jiang, Y. On Some questions of China English: The response on the article of "Questioning China English". Foreign Language Education,2003, 24(1), pp.27-35.

姜亚军. 有关中国英语的问题: 对 “ “中国英语”质疑”一文的 回应, 外语教学, 2003, 24 (1) ,27-35.

[21] Pan, Z. (2002). Retrospect and prospect of the study of Chinese English in China. Foreign Language Research, (6), pp.24-27.

潘章仙. 2002. 中国英语变体的研究一回顾与展望. 外语研究, (6) . 24-27

[22] Qiu, L. \& Ning, Q. Questioning 'China English' — discussion with Du Ruiqing and Jiang Yajun. Foreign Language Education,2002, 23(6), pp.23-27.

邱立中, 宁全新. “中国英语” 质疑一与杜瑞清、姜亚军先生 商榷. 外语教学, 2002, 23(6), 23-27.

[23] Wang, R. \& Chang, J. (2001). The origin of Chinese borrowing in English vocabularies, Journal of Sichuan Foreign Language University, 2001, 17(4). pp.70-73.

汪榕培, 常骏跃. 英语词汇中汉语借词的来源. 四川外语学院学 报，2001,17（4）.70-73. 